\title{
“A LIVING MOSAIC OF HUMAN BEINGS": THE LIFE WRITING OF VIRGINIA WOOLF AND ZITKALA-ŠA
}

\author{
Kristin Czarnecki ${ }^{1^{*}}$ \\ ${ }^{1}$ Georgetown College, Georgetown, KY, United States
}

\begin{abstract}
This essay examines life writing by English author Virginia Woolf (18821941) and Yankton Dakota writer Zitkala-Ša (1876-1938), specifically Woolf's memoir, "A Sketch of the Past," written in 1939-40 and first published in Moments of Being in 1976, and Zitkala-Ša's autobiographical essays, published in the Atlantic Monthly in 1900. This comparative study explores how both women establish selfhood amid competing pressures vying for their minds and bodies; how mothers and maternal loss shape their autobiographies; how physical and psychological place and displacement influence their life writing; and how matters of audience affect their literary self-portraits. Reading Woolf and Zitkala-Ša together yields fresh insights into the intersections of race, class, gender, and feminism in women's writing.

Keywords: Virginia Woolf; Zitkala-Ša; feminism; intersectionality; life writing
\end{abstract}

\footnotetext{
"English professor at Georgetown College and past president of the International Virginia Woolf Society. Her work has appeared in Woolf Studies Annual, Journal of Modern Literature, Journal of Feminist Scholarship, and Journal of Beckett Studies, among others, as well as in edited volumes. She has also published a memoir called The First Kristin: The Story of a Naming (Main Street Rag).E-mail: Kristin_Czarnecki@georgetowncollege. edu. ORCID: 0000-0003-0864-4401.
} 
Over several months in 1939 and 1940, Virginia Woolf wrote "A Sketch of the Past" (1985), memoirs she began in part as a break from writing her biography of Roger Fry. ${ }^{1}$ She relates her earliest impressions, her memories of her mother, and her response to her mother's death when she was thirteen. She writes of the aftermath of that death, her problematic relationship with her father, her and her sister Vanessa's maturity into adulthood, and the pressure exerted upon them by their half-brothers to comply with patriarchal social norms. She also considers the nature of biography, autobiography, and memory. Woolf's contemporary, Gertrude Simmons Bonnin, was born on the Yankton reservation in South Dakota in 1876, adopting the name Zitkala-Ša (Red Bird in Lakota) when she began publishing. In January, February, and March of 1900, Zitkala-Ša published three autobiographical pieces in the Atlantic Monthly. The first, "Impressions of an Indian Childhood," concerns her formative years on the reservation; "The School Days of an Indian Girl" recounts her experiences at boarding school and college; and "An Indian Teacher Among Indians" tells of her employment at Carlisle Indian Industrial School, founded by Lt. Col. Richard Henry Pratt in Carlisle, Pennsylvania, in 1879.

In their life writing, Woolf and Zitkala-Ša demonstrate comparable narrative strategies and feminist impulses. They fuse personal experience with social critique. And they recover and recuperate women's lives and stories while creating alternatives to hegemonic discourse. Significant differences of course exist between Woolf, raised in an upper-middle-class family in late Victorian England, and Zitkala-Ša, born at the height of America's "Indian Wars" and initiatives to eradicate Native languages, cultures, and spiritualities. Yet exploring their responses to patriarchal and colonial paradigms, how mothers and maternal loss shape their autobiographies, how physical and psychological place and displacement influence their lives and writing, and how matters of audience affect their literary self-portraits "enables us to chart an understudied genealogy of feminist critique in autobiographical forms," as Leigh Gilmore and Elizabeth Marshall explain in their 2019 study of intersectional women's life writing (14). Erica Gene Delsandro adopts a similar approach in her essay on Woolf and Mina Loy, women "so divergent in their lives that a comparison of the two should result in a study of contrasts. And yet the differences ... only make the affiliations more significant" ("Modernist Affiliations" 2020, 175). I concur in terms of comparative work on Woolf and Native women writers-work in which I have long been deeply engaged. ${ }^{2}$

As Rita Felski and Susan Stanford Friedman explain in Comparison: Theories, Approaches, Uses, the act of comparing is ingrained in us. We compare to distinguish, accept, reject, enhance our comprehension, and appreciate diversity. Grounds of comparison historically have been Euro-centric, however, so that often, Friedman states, "comparison replicates a system of dominance on a global scale.... To refuse comparison ... can potentially reinstate the existing hierarchies by not challenging them" $(2013,35,36)$. Patricia Okker similarly stresses that "if we are ever to create interpretive frames that do not exclude on the 
basis of race or gender or class, we must allow previously 'marginal' texts to help us reshape the interpretive frames themselves" $(1994,98)$. Delsandro concurs in her introduction to Women Making Modernism (2020), citing the importance of "alternative ways of reading and models of scholarship that challenge the exclusion and hierarchy of canonicity" (5). Adopting an "orientation of openness" (Delsandro 9) in our comparative work allows for better informed, more nuanced readings of individual texts and establishes transcultural dialogues for today's literary and feminist studies.

\section{Formative Experiences, Reimagined}

Virginia Woolf and Zitkala-Ša begin their life writing, understandably enough, with their earliest childhood impressions. For Woolf, these are inextricably linked with her family's summers at St. Ives as she recalls the play of light upon the sea, sand, and flowers and of "hearing the waves breaking, one, two, one, two, and sending a splash of water over the beach" (64). She remembers the quality of the air, the cawing of birds, and her mother standing on the balcony that connected Woolf's nursery with her parents' bedroom. Walking down to the beach, she would listen to the hum of bees in the garden, recalling the "buzz, the croon, the smell, [that] all seemed to press voluptuously against some membrane" (66). In recollection, she senses anew the "complete rapture of pleasure" she felt (66). For Woolf, it is her family's summers in Cornwall that constitute her most powerful early memories, summers she anticipated with joy on the train ride from London each year.

In "Impressions of an Indian Childhood," Zitkala-Ša similarly conjures a pastoral early environment in which her mother, Ellen Taté Iyóhiwin Simmons, raised her in traditional Dakota ways. She recalls herself as a girl of seven "free as the wind that blew my hair, and no less spirited than a bounding deer" (68). Spending the bulk of her days outside, Zitkala-Ša would follow and learn from her mother and teenaged female cousin as they performed their daily tasks. At night, her family and their guests would gather for meals and storytelling, ZitkalaŠa lying with her head in her mother's lap. Both writers evoke the intensity of these early, distinctly summer memories. In fact, Zitkala-Ša claims to have "few memories of winter days at this period of my life, though many of the summer" (82). At eight years old, she leaves the reservation to attend White's Manual Labor Institute, a Quaker boarding school for Native children in Wabash, Indiana. She would not see her mother or the reservation again for the next three years.

At the center of both women's life writing stand their mothers-the cherished yet sorrowful and at times remote women with traumatic past experiences their young daughters understand only vaguely. As "Impressions of an Indian Childhood" begins, Zitkala-Ša describes her mother as often "sad and silent" (68). Four of Zitkala-Šàs eight older siblings died in infancy, while another brother had been taken from their mother and raised by whites. The growing numbers of "palefaces" and their ongoing theft of Dakota land cause her mother 
to speak " $[w]$ ith a strange tremor in her voice," Zitkala-Ša states (69). Years later, when she has returned from boarding school, her mother senses her daughter's disconnection from Yankton life and alienation from the white world as well-a "deplorable condition" her mother is powerless to alleviate (69). In a haunting passage, she recalls being "suddenly aroused by a loud cry piercing the night. It was my mother's voice wailing among the barren hills which held the bones of buried warriors ... My fingers grew icy cold, as I realized that my unrestrained tears had betrayed my suffering to her, and she was grieving for me" (100).

Some years later, the two argue over whether Zitkala-Ša should return to the white man's school. Defying her mother, Zitkala-Ša heads to Earlham College in Indiana. At the end of her first and only year there, she becomes the first female student to give public orations. One memorable day, she wins second prize in a statewide college speech competition. Alone in her room later that evening, she feels unsettled. "The little taste of victory did not satisfy a hunger in my heart," she writes. "In my mind I saw my mother far away on the Western plains, and she was holding a charge against me" (103). Zitkala-Ša continues to live far from home and frames her life experiences in terms of her fraught relationship with her mother. Yet "Impressions of an Indian Childhood" highlights her mother's enculturation of her into Dakota lifeways, and she would go on to translate traditional Dakota stories into English to honor and preserve her mother's heritage. The ensuing book, American Indian Stories (2003), "corrects images that have been distorted through the lenses of Euro-American observers" (Spack 1997, 26). Rooted in Dakota matrilineal culture, Zitkala-Ša's writing resists the denigration of Native women wrought by colonization.

Virginia Woolf's mother, Julia, was a widow when she married Woolf's father, Leslie Stephen, her first husband having died when she was twenty-four years old and pregnant with their third child. Woolf recalls her mother's voice, "decided" and "quick" (81), her laugh, her hands, her "astonishing beauty" (82), and the day when Virginia ran to meet her on the path, and "she half turned from us, and lowered her eyes," an "indescribably sad gesture" (82). "She could be sharp," Woolf goes on; "she disliked affectation." She was "[s]evere; with a background of knowledge that made her sad" (83). Woolf's mother, like Zitkala-Ša’s, "had her own sorrow waiting behind her to dip into privately" (83). Julia died when Virginia was thirteen, an event she likens to a light going out, leaving a bereft family to navigate murky new waters. Summers at St. Ives also came to an end, for Leslie could not bear to be there without his wife.

Woolf strives to paint a portrait of her mother but finds it "curiously difficult to describe both my feeling for her, and her herself" (80). She also endeavored to recreate Julia in her fiction. In her 2004 study of Woolf's "ongoing internal relationship with her mother" (713), Katherine Dalsimer finds Woolf writing the "experience of [maternal] abandonment" in To the Lighthouse, for instance (714, original emphases), in which Mrs. Ramsay is the sun around which everyone else orbits. "I wrote the book very quickly," Woolf says, "and when it was written, I ceased to be obsessed by my mother. ... I suppose that I did for myself what 
psycho-analysts do for their patients. I expressed some very long felt and deeply felt emotion. And in expressing it I explained it and then laid it to rest" (81)a peculiar statement given that Woolf's reflections on her mother continue to tumble forth for the next several pages.

In To the Lighthouse, Dalsimer states, Woolf "does more than simply describe grief ... Woolf induces grief in the reader, inflicts it on the reader" (715, original emphases). Such is the dynamic in "Sketch" as well. When her mother died, she writes, "George took us down to say goodbye. My father staggered from the bedroom as we came. I stretched out my arms to stop him, but he brushed past me, crying out something I could not catch"-a poignant inversion of the bracketed announcement of Mrs. Ramsay's death in To the Lighthouse: "[Mr. Ramsay, stumbling along a passage one dark morning, stretched his arms out, but Mrs. Ramsay having died rather suddenly the night before, his arms, though stretched out, remained empty]" (132). Experiences of maternal love and loss shape Woolf's and Zitkala-Šass self-conception and engender their writing in myriad genres.

Woolf and Zitkala-Ša also contend with problematic patriarchal concepts of womanhood. For Woolf, it is the Angel in the House-the Victorian woman sanctified in Coventry Patmore's eponymous poem who sacrifices herself on the altar of domesticity. For Zitkala-Ša, it is the "squaw," a degrading caricature of Native womanhood. Woolf discusses her battle with the Angel in the House in her essay "Professions for Women," derived from a paper she read to the Women's Service League in 1931, and we see aspects of the Angel in the portrait of Julia Stephen that Woolf creates in "A Sketch of the Past": caring for a demanding husband and houseful of children as well as engaging in charitable works, nursing the sick, and performing the daily rituals expected of women of her social class. Woolf's half-sister Stella stepped into this role after Julia's death, and Woolf recounts the slow erosion of Stella's young womanhood at the impossible demands and moods of Leslie Stephen. Upon Stella's untimely death, Woolf's half-brothers, George and Gerald Duckworth, stepped in to groom her and Vanessa for precisely the same role.

Zitkala-Ša's victory in the collegiate speech competition is blighted not only by her vision afterwards of her disapproving mother but also by a racist and sexist prank played during the event. When the orations have finished, students from a rival school unfurl a large white banner "with a drawing of a most forlorn Indian girl on it," she writes. "Under this they had printed in bold black letters words that ridiculed the college which was represented by a 'squaw"' (79). As Paula Gunn Allen explains, however, the word "squaw" was originally a term of honor and respect. The "sunksquaw" of a tribe was its "hereditary female head of state" (1992, 34). That "squaw" became an insult leveled against Native women by whites is "only another example of patriarchal dominance," Allen states (273). Ruth Spack points out as well that "the journals, diaries, and letters of Euro-American travelers and traders . . . described American Indian women's work as 'menial' and viewed the women themselves as 'beasts of burden,' 'slaves', and 'brutes' who were 'sexually lax,' 'uncultivated,' and 'inferior' and who lived a life of 'barbarism' and drudgery"' 
(27). Zitkala-Ša reconstructs Native womanhood in her essays, depicting women's tasks, such as drawing water and building fires, as "activit[ies] of high status" and "in language that has a positive connotation" (Spack 29).

Both women write of other problematic aspects of their lives. Zitkala-Ša tells of hearing a haunting story of "a woman whose magic power lay hidden behind the marks upon her face," so that forever after, she harbors a suspicion of tattooed people. And while her mother refrains from sharing details with her young daughter on the persecution of their people, Zitkala-Ša recalls her mother's grim expression whenever she mentioned the "paleface," deeming him "a sham-a sickly sham" and pointing to nearby burial sites of relatives who died during forced removal from their land (69). Indeed Zitkala-Šàs title for this essay, "Impressions of an Indian Childhood," suggests the erosion of her people's way of life due to white encroachment. She also recalls the arrival of missionaries as heralding "[ $\mathrm{t}]$ he first turning away from the easy, natural flow of my life" (83). Unlike Woolf's joyous train rides to St. Ives, Zitkala-Ša’s first train ride, to boarding school, proves mortifying as white people gawk at the Native children. The landscape similarly portends a bewildering, unnatural new world. "I was quite breathless upon seeing one familiar object" while looking out the window, she writes. "It was the telegraph pole which strode by at short paces." She recalls having seen them on the reservation, where she had sometimes "stopped ... to hold my ear against the pole, and, hearing its low moaning, I used to wonder what the paleface had done to hurt it" (88).

In "A Sketch of the Past," Woolf also recalls complex, confusing aspects of her childhood, such as the wave of despair that washes over her while physically fighting with her brother Thoby, of overhearing her parents discuss the suicide of a man who had recently been a guest in their home, and of feeling ashamed at age six or seven of looking in the mirror, something she only did when alone. "I was ashamed of it," she writes. "A strong feeling of guilt seemed naturally attached to it. One obvious reason occurs to me-Vanessa and I were both what was called tomboys; that is we played cricket, scrambled over rocks, climbed trees ... Perhaps therefore to have been found looking in the glass would have been against our tomboy code" (68) Similar to Zitkala-Ša, young Virginia Stephen reveled in the outdoors, and initially, it is her fear of betraying Vanessa that brings about what she calls her "lookingglass shame." It runs deeper, though, she suspects, musing that an inherited Puritan streak on her father's side has led to her mortification concerning anything to do with the body, such as wearing makeup or trying on clothes. ${ }^{3}$

An especially devastating parallel between Woolf and Zitkala-Ša is the violation each endures as a child. After discussing her "looking-glass shame," Woolf considers another probable explanation for being "ashamed or afraid of my own body" (68): the time Gerald lifted her onto a "slab outside the dining room" and "began to explore [her] body" when she was about six years old (69). ${ }^{4}$ She takes her readers through the experience step by step: Gerald's fingers beginning to touch her, going under her clothing, and approaching her private parts as she, paralyzed with fear, hopes it will stop. "But it did not stop," Woolf 
writes. "I remember resenting, disliking it" (69). She surmises that children must harbor an instinctive sense that certain parts of their bodies must not be touched. Woolf continued to reflect on this incident, for instance in letters to her friend Ethel Smyth, up until the time of her death. ${ }^{5}$

In "School Days of an Indian Girl," Zitkala-Ša writes of the swiftness with which boarding school teachers stripped Native children of all they knew. They gave them Anglo names, replaced their blankets and moccasins with Western attire and wooden shoes, and forbid them from speaking their native languages. The natural rhythms of life were replaced with militaristic routines and arbitrary rules and punishments. While these were terrible trials to be borne, the most grievous incident for Zitkala-Ša was the cutting of her hair. "Among our people," she explains, "short hair was worn by mourners, and shingled hair by cowards!" (90). Learning from another child that her hair will be cut, she hides, writing of the ensuing violence when the teachers find her. Dragging her out from under a bed as she kicks and cries, they carry her downstairs and tie her to chair. A moment later, she feels "the cold blades of the scissors against my neck, and heard them gnaw off one of my thick braids. Then," she writes, "I lost my spirit" (91). In contrast to the summers recounted in "Impressions of an Indian Childhood," the episodes in "School Days of an Indian Girl" occur in winter, establishing a stark binary between her two worlds. Later, she sets her college experiences in winter as well.

\section{(De)Constructing Binaries}

Zitkala-Ša’s emphasis upon binaries in her essays invites consideration of a hallmark of literary modernism and of Virginia Woolf's writing in particular: the dismantling of binaries, which deny the multiplicity of human experience and consciousness. Throughout her work, Woolf rejects false dichotomies such as public/private, sane/insane, feminine/masculine. She demonstrates the damage wrought by binaries, proposing instead broader and deeper ranges of human experience, such as the commingling of past and present in Mrs. Dalloway (1925) and the fluidity of gender and sexuality in Orlando (1928) and A Room of One's Own (1929). In doing so, she reflects a millennia-old Indigenous worldview. Tribes-people "acknowledge the essential harmony of all things," Paula Gunn Allen explains, "and see all things as being of equal value in the scheme of things, denying the opposition, dualism, and isolation (separateness) that characterize non-Indian thought" (56). Zitkala-Ša's critique of the forced assimilation of Native peoples demands contrasts, however. Reading her autobiographical essays alongside Woolf's memoir allows us to appreciate the value of binaries for women striving to assert their selfhood amid a dominant power structure determined to denigrate or disregard their voices.

Depicting binary Native and white worldviews, Zitkala-Ša "reverses entrenched American narratives" (Lewandowski 2016, 153). Anglo concepts of "civilized" and "savage" fall apart in scenes of boorish white families on the train, violent white teachers at boarding school, and the "barbarian rudeness" of 
the white students who pranked her at the collegiate speech competition (79). "By strategically inverting the civilized-savage polarity," writes Patrice Hollrah, "Zitkala- Ša demonstrates who the truly civilized person is in this scenario-the Indian" $(2004,39)$. My reading of Zitkala-Šàs deployment of binaries as essential to her affirmation of Native ways differs from Ron Carpenter's view of the Atlantic Monthly pieces. "Throughout the autobiography," he states, "Zitkala-Ša's narrator avoids defining herself prescriptively according to either Yankton or Anglo culture. [Her] persona is bicultural ... in order to reconfigure the representation of Native Americans and their cultural status" $(2004,1)$. Zitkala-Ša was born after relocation, he notes, therefore not into an Edenic pre-contact world, and she writes of Anglo aspects of her early life, such as a coffee pot, a canvas tipi, Bibles and marbles distributed by missionaries, and, later, her mother's log cabin. "In short," Carpenter writes, "Zitkala-Ša's life story is framed as an interfusion of cultural practices" (5).

While this holds true to a degree, Zitkala-Ša's rendition of events is more complicated. For example, her father was a white man whom she never knew, but in her Atlantic Monthly essays, she "portray[s] herself as a full-blood," as Penelope Myrtle Kelsey notes (2010, 70). Considering Zitkala- Ša's motivation for presenting her father as Dakota, Kelsey surmises that her "aware[ness] of negative stereotypes of mixed-bloods as somehow degenerate" prompted her to try to "limit the range of racial fantasy she had to address" (71). I maintain as well that underscoring binaries provides Zitkala-Ša with a means of overturning Anglo stereotypes of Native peoples, ultimately pointing to the ineffectiveness of binaries to characterize human life.

Indeed, binaries become increasingly complex for Zitkala-Ša as her story continues. During her first visit back to her reservation after three years away, she feels disconnected from her Yankton home as well as the white world, and she laments her liminal state. "I was neither a wee girl nor a tall one," she writes, "neither a wild Indian nor a tame one. This deplorable situation was the effect of my brief course in the East, and the unsatisfactory 'teenth' in a girl's years" (97). As Sandra Kumamoto Stanley argues, "Zitkala- Ša’s work escapes the easy binary opposition in which the self is pitted against the other, the minority voice against the dominant culture. For finally, the self is a site of continual displacement, in which multiple voices must interrogate cultural presuppositions" (1994, 67). Later, in "An Indian Teacher Among Indians," Zitkala- Ša decides to teach at an "Eastern Indian" school, thereby conflating west/east, Native/white.

Virginia Woolf, in fact, also frames her early experiences in terms of binaries, particularly when recalling the atmosphere of her childhood home. As Georgia Johnston points out, writing her memoirs "forces [Woolf] to create a false innocent space and forces her to include those very divisions she abjures" $(2003,286)$, such as when recounting the supposedly "innocent, pre-ideological space [of childhood] ... when her mother was alive" (292). Later, Woolf recalls the pressures of late-Victorian society, which "in those days was a very competent machine. It was convinced that girls must be changed into married women. It 
had no doubts, no mercy; no understanding of any other wish; of any other gift" (135). When she tells a distinguished elderly visitor to the family home that she wishes to write, the woman "snapped [that] I was silly" (135). The only freedom to be had exists on the upper floors of the house, where she has carved out the space to write and Vanessa to paint, and where they talk with Thoby about his Cambridge experiences. "The division in our life was curious," Woolf writes. "Downstairs there was pure convention: upstairs pure intellect. But there was no connection between them" (136).

This sense of competing physical and ideological spaces causes confusion for Woolf just as it had for Zitkala-Ša, and she writes of it in a similar cadence and tone. As "A Sketch of the Past" draws to a close, Woolf muses on the illustrious visitors to her childhood home, such as Watts, Meredith, and Henry James:

There they were on the verge of the drawing room, these great men: while, round the tea table, George and Gerald and Jack talked of the Post Office, the publishing office, and the Law Courts. And I, sitting by the table, was quite unable to make any connection. There were so many different worlds: but they were distant from me. I could not make them cohere; nor feel myself in touch with them. And I spent many hours of my youth restlessly comparing them. No doubt the distraction and the differences were of use; as a means of education; as a way of showing one the contraries. (137)

Writing her memoirs allows Woolf to gauge the possible value of such a divide.

Similarly, writing her essays enables Zitkala-Ša to respond in ways she could not have as a child to the cultural genocide perpetrated at boarding school. As Gilmore and Marshall explain, the adult writer "return[s] to the experiences of [her] own girlhood to offer fine-grained and strategically shaped accounts of childhood that allow new audiences to understand [her] vulnerability and suffering, but also the role that authorities played in enabling violence" (2-3).

At boarding school, every aspect of the children's Native heritage was confiscated, demeaned, and often beaten out of them. Although Zitkala-Ša does not write of it, sexual abuse ran rampant, and thousands of children died from disease or malnutrition. Those who lived were generally not permitted to go home; some did not see their families for five years or more as school administration and governmental policy sought to destroy Native familial and tribal bonds. Many children returned home no longer able to speak their native language. As Martha J. Cutter observes, at boarding school, Zitkala-Ša "loses the mother and the mother tongue" $(1994,35)$. Crying inconsolably on her first night there, she is "tucked into bed with one of the tall girls, because she talked to me in my mother tongue and seemed to soothe me," she writes (89). More often, however, "Not a soul reasoned quietly with me, as my own mother used to do; for now I was only one of many little animals driven by a herder" (91).

Woolf also employs animal imagery in recounting her abuse. She tells of a dream in which she "was looking in a glass when a horrible face-the face of an animal-suddenly showed over my shoulder" (69). She wonders if this might 
have actually happened; either way, she says, "it frightened me" (69). As Laura Marcus writes, "Dream or fact: the undecidability of this 'memory' does nothing to undermine the 'truth' of the incident with Gerald Duckworth, but it does indicate Woolf's acute awareness of the complexities of remembering" (2017, 270). I read the animal face in the mirror as reflective of young Virginia Stephen's sense of the predatory males within her home. In Emily Dalgarno's view, "A Sketch of the Past" is "a tale of the female child's acculturation in the patriarchal world" $(1994,176)$. Indeed, her half-brothers would continue to badger and shame her in late adolescence, pressuring her to dress, speak, and behave a certain way on outings to dinners and parties. She relates a scene in which the expression on George's face when she descends the stairs in a dress he finds unacceptable plunges Virginia Stephen into a paroxysm of humiliation and regret.

\section{Rhetorical Resistance, Cultural Critique}

For Woolf and Zitkala-Ša, these troubling and traumatic incidents have personal and cultural implications that influence them for years to come. Each woman recalls her ambivalence and disorientation at the pressure upon body and mind to assimilate to patriarchal social codes. Back home after several years at boarding school, Zitkala-Ša exchanges her Western clothing for traditional dress yet envies the older teenagers as they head to a party in Western attire, speaking English. In the same vein, although she and Vanessa abhor the society valued by their Duckworth brothers, Woolf, as Virginia Stephen, had complied. "I must obey," she writes, "because [George] had force, of age, of wealth, of tradition, behind him" (132-2). Their resistance soon emerges, however. ZitkalaŠa subverts her teachers' instructions while appearing to follow them and defaces depictions of the devil in the Bible meant to terrify her into submission, in this way materially altering the script of enforced assimilation and, as Rachel Ihara and Jaime Cleland explain, asserting the value of oral culture as opposed to the "vulnerability of stories translated into print" $(2011,72)$. Her tactics manifest "survivance," Gerald Vizenor's neologism blending survival and resistance, as does her defiance in having her hair cut. "No, I will not submit. I will struggle first!" she cries (90), reflecting a strong sense of heritage and custom imbibed "from a culture that did not devalue females, as the dominant Euro-American society did" (Dominguez 2003, xii).

Virginia Stephen, with her burgeoning feminist sensibilities, forms a united front with Vanessa against their male relations. She recounts "the horror of Wednesday," for instance, when Vanessa presented the weekly accounts to their father. "Down came his fist on the account book," Woolf writes (124). "There was a roar. His vein filled. His face flushed. Then he shouted, 'I am ruined.' Then he beat his breast" and shouted at Vanessa, impassively standing by. After explaining her compulsion to obey George, Woolf writes, "But even while I obeyed I asked, 'How could anyone believe what he believed'?" (133). Regarding the dress incident, she senses George’s displeasure stemming from "not merely aesthetic 
disapproval; but something that went deeper; morally, socially, he scented some kind of insurrection; of defiance of social standards" (130). Woolf's fortitude grows increasingly stronger in adulthood. Her entire corpus critiques private and public manifestations of patriarchal oppression.

Woolf also reflects on the lasting effect upon her of the eruptions of tragedy into her young life:

to be tumbled out of the family shelter, to see cracks and gashes in that fabric, to be cut by them, to see beyond them-was that good?... I came to think of life as something of extreme reality. And this, of course, increased my feeling of my own importance. Not in relation to human beings: in relation to the force which had respected me sufficiently to make me feel what was real. (118)

As Marcus explains, writing "A Sketch of the Past" enables Woolf to attain selfknowledge as she "describes an evolution of the self" (268).

Zitkala-Ša also ponders the extreme realities contributing to her sense of a developing self along with her growing discontent with the boarding school regime. In "An Indian Teacher Among Indians," she writes of her decision as a young woman to leave her mother and the reservation yet again, this time to teach at Carlisle, which was pleased to employ her. She was a fast learner, a model student, a gifted musician, a winner of academic prizes. Shortly after Zitkala-Ša arrived at Carlisle, Pratt sent her back West to recruit Native students. On this trip home, she learns more about the brutal conditions on the Yankton reservation. With her mother too old to bead anymore and her brother having lost his job to a white man, the family has no stable source of income. They are low on food, and her mother's home is shoddily built and drafty. She tells Zitkala-Ša that "this village has been these many winters a refuge for white robbers" (109), language again conflating whites with winter. "The Indian cannot complain to the Great Father in Washington," her mother continues, "without suffering outrage for it here" (109). Zitkala-Ša returns to Carlisle with a far more critical outlook on Indian education, and she begins to write. As Spack notes, she "was among those whom the system labeled success stories until she began to use the English language in subversive ways ... adopt[ing] trickster strategies ... to dupe white readers into recognizing the value of her linguistic and cultural background" (26).

In "An Indian Teacher Among Indians," Zitkala-Ša recalls being "watched by those around me" (106), reminiscent of George and Gerald Duckworth's surveillance of their Stephen sisters. She tells of self-serving, incompetent, inebriated white teachers and doctors, given jobs through favoritism or nepotism and wreaking havoc upon the psychological and physical well-being of the children. When the President of the United States sends inspectors to the schools, they see "the students' sample work made for exhibition. I was nettled by this sly cunning of the workmen who hoodwinked the Indian's pale father at Washington" (111). She refers to her awakening as "my own evolution" and regrets past decisions: 
For the white man's papers I had given up my faith in the Great Spirit. For these same papers I had forgotten the healing in trees and brooks. On account of my mother's simple view of life, and my lack of any, I gave her up, also. I made no friends among the race of people I loathed. ... [F] ew there are who have paused to question whether real life or long-lasting death lies beneath this semblance of civilization. (113)

Jessica Enoch states that Zitkala-Ša "found an unmonitored discursive space in the Atlantic Monthly" in which to critique the boarding schools $(2002,123)$, yet her essays provoked a "vituperative campaign to discredit [her] as a reputable chronicler of Indian education” (Lewandowski 45). Carlisle administrators accused her of lying, claiming that some of the events she relates happened to other children or are composite experiences. An article in Red Man, a Carlisle periodical, "charged that 'many of the incidents are purely fictitious and often the situation is dramatically arranged to produce the desired effect"' (Lewandowski 49). "Seeking to deflect her criticisms," Lewandowski writes, "the article painted the aspiring author as an ungrateful prodigal daughter who had employed tawdry literary techniques to illicit [sic] sympathy among uninformed readers" (49). The article even "suggested that the idea of white settlers occupying reservation land was absurd. Most galling, however, according to the article, was Zitkala-Ša's 'contempt and disgust' for her former benefactors. This attitude showed her to be 'a person of infinite conceit"' (Lewandowski 49). Pratt, too, was critical. "But for those she has maligned," he wrote in a letter, "she would be a poor squaw in an Indian camp, probably married to some no-count Indian" (qtd. in Lewandowski 46).

Adding fuel to the fire, Zitkala-Ša then published an essay called "The Great Spirit," originally titled "Why I Am a Pagan." In Wordsworthian fashion, she reflects upon the experience of immersing herself in nature and reaches a higher plane of spirituality leading to a revelation-cum-social critique:

Finally resuming the chair at my desk I feel a keen sympathy with my fellow-creatures, for I seem to see clearly again that all are akin. The racial lines, which once were bitterly real, now serve nothing more than marking out a living mosaic of human beings. And even here men of the same color are like the ivory keys of one instrument where each resembles all the rest, yet varies from them in pitch and quality of voice.... Thus ... I greet the solemn-faced 'native preacher' whom I find awaiting me. I listen with respect for God's creature, though he mouth most strangely the jangling phrases of a bigoted creed. (116)

In "The Great Spirit," she defiantly proclaims the value of her Dakota worldview while dispensing with false binaries, now, that drive people apart.

Woolf's reflections on her experiences along with her writing practice lead to a similar conclusion concerning humankind's interconnectedness:

I always feel that [these sudden shocks] are particularly valuable. And so I go on to suppose that the shock-receiving capacity is what makes me a 
writer. ... It is only by putting [the experience] into words that I make it whole; this wholeness means that it has lost its power to hurt me; it gives me, perhaps because by doing so I take away the pain, a great delight to put the severed parts together. Perhaps this is the strongest pleasure known to me. It is the rapture I get when in writing I seem to be discovering what belongs to what ... From this I reach what I might call a philosophy; at any rate it is a constant idea of mine; that behind the cotton wool is hidden a pattern; that we-I mean all human beings - are connected with this; that the whole world is a work of art. (72-3)

Life writing allows both women to parse complex experiences, interrogate sociopolitical norms, and formulate theories of art and humanity along with the bases of their own resilience.

In "The Great Spirit," for instance, a Native preacher, a convert to Christianity, asks Zitkala-Ša why she does not attend church. He then resorts to scare tactics, speaking of hellfire and an "evil hand" clutching "braided dry grass" (117), an allusion to Indigenous purification practices. Batting away the preacher's words like so many flies, Zitkala-Ša offers him a meal, a gesture of hospitality, for he is nevertheless a fellow Dakota. Referring to his scolding of her as the "little incident," she diminishes his attempts to demean Native ways and impose Christianity upon her. As the essay closes, she considers herself a "wee child toddling in a wonder world ... prefer[ring] to their [Christian] dogma my excursions into the natural gardens where the voice of the Great Spirit is heard in the twittering of birds, the rippling of mighty waters, and the sweet breathing of flowers" (117). Evoking the "wee child" of her reservation upbringing, she reclaims her earlier uncompromised Dakota identity.

Those who alleged the deceptive nature of Zitkala-Ša's Atlantic Monthly essays decried the sentiments expressed in "The Great Spirit" as well, all of which has played a role in her literary legacy. ${ }^{6}$ In considering Zitkala-Ša's exclusion from the traditional American literary canon, for instance, Martha J. Cutter writing in 1994 finds that her "writing has been judged deficient precisely because it does not conform to canonical models of autobiography" (32), meaning white, male, and individualistic. As Carpenter notes, "She avoids many biographical details that would make the text too subjective ... disturb[ing] the inherent egotism of most self-representational texts.... By explicating the general experiences of Indian children, the narrator helps expand conceptions of autobiography beyond the egocentric" (12-13). Gilmore's study of women's life writing corroborates Cutter's and Carpenter's summations. Gilmore finds traditional "autobiography draw[ing] its social authority from its relation to culturally dominant discourses of truth telling" wherein "autobiography criticism participates in 'policing truth' . . . in effect, criminaliz[ing] certain autobiographers” $(1994,14)$. Scholars today recognize Zitkala-Ša's essays as semiautobiographical expositions of necessary truths-imbrications of her own experiences along with those of other Native peoples. ${ }^{7}$ 


\section{Modes of Life Writing}

Zitkala-Ša reworks the genre of autobiography in a distinctly Native, feminist context to criticize white society's brutalization of Indigenous peoples. In her first two essays in particular, "[h]er adult self provided the language denied to her younger self and, in a sense, accompanied the child witness, doubling back to seek justice, amplifying her own voice, and standing in the place of the victim as a survivor," as Gilmore and Marshall explain of women's autobiographical accounts of childhood (2). In the same vein, Zitkala-Ša stands among early minority writers who "deploy autobiography to construct identities as writers and artists" (Ihara and Cleland 64). While her essays "blur the distinction between fact and fiction," as Spack states, such "an approach allows readers to separate the loss of control of language that the first-person female narrator sometimes experiences from the rhetorical control that the author always maintains" (29). In this way, Zitkala-Ša's life writing resembles Virginia Woolf's A Room of One's Own, which similarly resists categorization. "[C]all me Mary Beton, Mary Seton, Mary Carmichael or by any name you please-it is not a matter of any importance," says the narrator of Room as she sets out to explore the effects of gender and gender discrimination upon women's writing (5). As Dalgarno states, the first paragraphs of Room "assert the fictional status of the autobiographical 'I"' (177).

The arc of "A Sketch of the Past" bends in a similar direction, reflecting Woolf's lifelong fascination and frustration with biography. Woolf questions what it means to know a person, to write about a life meaningfully, and whether either is possible. ${ }^{8}$ She enjoys reading biographies but faults them for "leav[ing] out the person to whom things happened," for "it is so difficult to describe any human being" (65). As Gillian Beer explains, "The knowing biographer is on a par with the realist novelist in [Woolf's] judgment: they both claim an authority which stifles their awareness of life" $(1996,57)$. Early in "A Sketch," Woolf sets down facts about herself. "Who was I then? Adeline Virginia Stephen, born on $25^{\text {th }}$ January 1882 , descended from a great many people, some famous, others obscure ... But I do not know how much of this, or what part of this, made me feel what I felt in the nursery at St. Ives. I do not know how far I differ from other people. That is another memoir writer's difficulty" (65). According to Marcus, "there is the strongest recognition in ... Sketch of the Past that the interest of autobiography lies not in events but in identities and feelings" (268). Similar to Spack's assessment of Zitkala-Ša’s narrative innovations, Dalsimer finds Woolf "summon[ing] [the past] into being through the vividness of her own imagination"; thus "[f]rom the scraps of information she had, from the anecdotes she had been told, from memories of her own, she made deductions, drew conclusions" (720). "This is how I shape it," Woolf explains of her "rough visual description of childhood" (79). Hermione Lee finds that "[i]n its refusal to make any pretence at a polished, coherent presentation of the 'self,' 'Sketch of the Past' begins to look like that new kind of women's life writing she has been recommending for so long" $(1997,18)$. 
One such recommendation appears in "The New Biography" (1967), an essay Woolf published in 1927 while she was writing Orlando, a mock biography of Vita Sackville-West and a critique of the patriarchal literary establishment she will carry forward into A Room of One's Own. In this essay, Woolf considers "the whole problem of biography ... On the one hand there is truth; on the other there is personality. And if we think of truth as something of granite-like solidity and of personality as something of rainbow-like intangibility and reflect that the aim of biography is to weld these two into one seamless whole, we shall admit that the problem is a stiff one" (229). She explores how the ponderous weight of facts-the granite-fails to convey personality-the rainbow. "For in order that the light of personality may shine through," she writes, "facts must be manipulated; some must be brightened; others shaded" (229). The biographer free of constraint and custom would "tell a fine tale with a flourish," she says (231), and she detects such freedom in the biographer of the early twentieth century: "He chooses; he synthesizes; in short, he has ceased to be the chronicler; he has become an artist" (17). "A Sketch of the Past" finds Woolf applying such tenets to memoir, too, as she becomes more invested in finding a means of recording childhood impressions than in establishing a linear sequence of events.

In her life writing, Zitkala-Ša similarly chooses, synthesizes, brightens, and shades, for example in "Impressions of an Indian Childhood," a title denoting the rainbow-like essence of the piece. "Cleverly," Lewandowski states, "she draws on biblical motifs to upend the temptation of Eve in her own experience. Christian missionaries lure her, the young Gertrude, from her Edenic home on the Yankton reservation" with the promise of bright red apples (40). ${ }^{9}$ As previously noted, Zitkala-Ša suspends her boarding school experiences in winter, and in "An Indian Teacher Among Indians," her sense of dislocation and fading Dakota sensibilities find expression in her previously cited image of the telegraph pole. Disheartened by her experience at Carlisle, she envisions herself "Like a slender tree ... uprooted from my mother, nature, and God. I was shorn of my branches, which had waved in sympathy and love for home and friends. The natural coat of bark which had protected my oversensitive nature was scraped off to the very quick. Now a cold bare pole I seemed to be, planted in a strange earth" (112). Both women hone their artistry as they shape their stories.

In closing, I mention two additional works that when read together highlight important affinities and contrasts between these two writers: the picture book Virginia Wolf, by Kyo Maclear and Isabelle Arsenault (2012), and the picture book biography Red Bird Sings: The Story of Zitkala- Ša, Native American Author, Musician, and Activist, by Gina Capaldi and Q. L. Pearce (2011). ${ }^{10}$ Virginia Wolf depicts in spare prose a depressive episode in the life of young Virginia, while her sister Vanessa valiantly tries to cheer her up. She succeeds by making a "Bloomsberry" of their bedroom: painting flowers, butterflies, birds, and trees in exuberant colors upon the walls. The picture book biography of Zitkala-Ša is more straightforward and text-heavy, adapting portions of the Atlantic Monthly essays and incorporating secondary source material as well. ${ }^{11}$ One book is 
impressionistic, attending to psychological interiority and the power of art. The other depicts a young life marred by oppression but rejuvenated through talent and resilience-different lives, different books that offer a rich cross-cultural portrait of Virginia Woolf, Zitkala-Ša, and women's life writing.

Notes

1. "I write by fits and starts by way of a holiday from Roger," Woolf notes on May 2, 1939 (75). And on May 15: "The drudgery of making a coherent life of Roger has once more become intolerable, and so I turn for a few day's [sic] respite to May 1895 " (85). Emily Dalgarno cites a confluence of factors prompting Woolf to begin her memoirs in earnest at this time (177).

2. An early version of this essay was published in Virginia Woolf and Her Female Contemporaries: Selected Papers from the Twenty-Fifth Annual International Conference on Virginia Woolf, Ed. Julie Vandivere and Megan Hicks. Also see my publications "'Strong Women Make Strong Nations': Women, Literature, and Sovereignty in Paula Gunn Allen and Virginia Woolf," "Melted Flesh and Tangled Threads: War Trauma and Modes of Healing in Virginia Woolf's Mrs. Dalloway and Leslie Marmon Silko's Ceremony," "Two-Spirits and Gender Variance in Virginia Woolf's Orlando and Louise Erdrich's The Last Report on the Miracles at Little No Horse," and "Unblowing, Ungrowing Are the Roses There': Violence Against Women and the Land in Virginia Woolf's Between the Acts and Louise Erdrich's The Round House."

3. Laura Marcus examines the role of shame in "A Sketch of the Past" along with "philosophical and psychological explorations of shame" more broadly (270).

4. See Alex Zwerdling's "Mastering the Memoir: Woolf and the Family Legacy" for an overview of theories regarding the sexual abuse Woolf suffered (166).

5. As Marcus points out, Woolf wrote to Smyth on January 12, 1941, "I still shiver with shame at the memory of my half brother, standing me on a ledge, aged about 6 , and so exploring my private parts. Why should I have felt shame then? But why should I be writing about these sexual speculations now?" $(L 6,460)$.

6. See Lewandowski's "Changing Scholarly Interpretations of Gertrude Bonnin (Zitkala-Ša)" (2019) for a thorough overview of Zitkala-Ša's critical reception.

7. "Thus, for Zitkala-Sa [sic], the private self is also a cultural construct," writes Stanley in her study of Zitkala-Ša and autobiographical strategies (64). Spack, on the other hand, "treat[s] [the Atlantic Monthly pieces] as fiction, for I believe that such an approach allows readers to separate the loss of control of language that the first-person female narrator sometimes experiences from the rhetorical control that the author always maintains. At the same time," she says, "it is important to acknowledge ... the autobiographical truth in the writing" (29).

8. Zwerdling suggests we "consider the whole mass of Woolf's autobiographical writings as a deliberately fragmented ongoing project" that "she had no intention of publishing" (167). In the same vein, Shari Benstock refers to Woolf's "effort at writing her own memoirs" (12, my emphasis) and even states, curiously to my mind, "Woolf did not live to write her memoirs" (17). Dalgarno also claims that "Sketch" was never intended for publication (178). Conversely, Hermione Lee states that "A Sketch of the Past" was "clearly intended for publication" (18).

9. Zitkala-Ša's trope here is prescient, for in later years, "apple" would become an epithet for so-called assimilated Natives: red on the outside, white on the inside.

10. "Teaching Dissent through Picture Books: Girlhood Activism and Graphic Life Writing for the Child," the fourth chapter in Gilmore and Marshall, explores 
how "[1]ife writing for children offers another 'alternative jurisdiction' through which adult women testify to harm and call for action" (86). The authors "include picture books" in their study of intersectional life writing "as a distinct form of child witness" (86). In particular, the chapter's analysis of the picture book biography Brave Girl: Clara and the Shirtwaist Makers' Strike of 1909," by Michelle Markel and Melissa Sweet, about Jewish labor activist Clara Lemlich, resonates strongly with the picture book biography of Zitkala-Ša, for instance in the way it "constructs a child activist who reclaims her experience as a collective one and calls on her audience to take an ethical stance" (87).

11. Like Red Bird Sings, Brave Girl includes a bibliography of primary and secondary sources. "The inclusion of these primary historical documents is purposeful," Gilmore and Marshall write: "They are easy to access online and open up an archive of materials that foreground a feminist, intersectional history of the working class in the United States" (99)_ just as the materials noted at the end of Red Bird Sings encourage teachers and children to learn more about the boarding schools and Indigenous struggles.

\section{References}

Allen, Paula Gunn. The Sacred Hoop: Recovering the Feminine in American Indian Traditions. Beacon Press, 1992.

Beer, Gillian. Virginia Woolf: The Common Ground: Essays by Gillian Beer. University of Michigan Press, 1996.

Capaldi, Gina, and Q. L. Pearce. Red Bird Sings: The Story of Zitkala-Ša, Native American Author, Musician, and Activist. Illustrated by Gina Capaldi, Carolrhoda Books, 2011.

Carpenter, Ron. "Zitkala-Ša and Bicultural Subjectivity." Studies in American Indian Literatures, vol. 16, no. 3, 2004, pp. 1-28.

Cutter, Martha J. "Zitkala-Ša's Autobiographical Writings: The Problems of a Canonical Search for Language and Identity." MELUS, vol. 19, no.1, 1994, pp. 3144.

Dalgarno, Emily. "Ideology into Fiction: Virginia Woolf's 'A Sketch of the Past."' NOVEL: A Forum on Fiction, vol. 27, no. 2, 1994, pp. 175-95.

Dalsimer, Katherine. "Virginia Woolf: Thinking Back Through Our Mothers." Psychoanalytic Inquiry: A Topical Journal for Mental Health Professionals, vol. 4, no. 5, 2004, pp. 713-30.

Delsandro, Erica Gene, ed. "Introduction: Making a Feminist Modernist Studies." Women Making Modernism. University of Florida Press, 2020, pp. 1-18.

"Virginia Woolf and Mina Loy: Modernist Affiliations." Women Making Modernism. University of Florida Press, 2020, pp. 174-202.

Dominguez, Susan Rose. "Zitkala-Ša: The Representative Indian." Introduction to American Indian Stories, by Zitkala-Ša. University of Nebraska Press, 2003, pp. $\mathrm{v}-\mathrm{xxv}$.

Enoch, Jessica. "Resisting the Script of Indian Education: Zitkala-Ša and the Carlisle Indian School." College English, vol. 65, no. 2, 2002, pp. 117-41.

Felski, Rita, and Susan Stanford Friedman. Comparison: Theories, Approaches, Uses. The Johns Hopkins University Press, 2013.

Friedman, Susan Stanford. "Why Not Compare?” In Felski and Friedman, pp. 34-45.

Gilmore, Leigh. Autobiographics: A Feminist Theory of Women's Self-Representation. Cornell University Press, 1994. 
Gilmore, Leigh, and Elizabeth Marshall. Witnessing Girlhood: Toward an Intersectional Tradition of Life Writing. Fordham University Press, 2019.

Hollrah, Patrice. "The Old Lady Trill, the Victory Yell": The Power of Women in Native American Literature. Routledge, 2004.

Ihara, Rachel, and Jaime Cleland. "Ethnic Authorship and the Autobiographical Act: Zitkala-Ša, Sui Sin Far, and the Crafting of Authorial Identity." Selves in Dialogue: A Trans-ethnic Approach to American Life Writing. Ed. Begona Simal. Rodopi, 2011, pp. 63-79.

Johnston, Georgia. "Politics of Retrospective Space in Virginia Woolf's Memoir 'A Sketch of the Past." Mapping the Self: Space, Identity, Discourse in British Auto/ Biography. Ed. Frédéric Regard. Publications de l'Université de Saint-Etienne, 2003, pp. 285-96.

Kelsey, Penelope Myrtle. Tribal Theory in Native American Literature: Dakota and Haudenosaunee Writing and Indigenous Worldviews. University of Nebraska Press, 2010.

Lee, Hermione. Virginia Woolf. Knopf, 1997.

Lewandowski, Tadeusz. Red Bird, Red Power: The Life and Legacy of Zitkala-Ša. University of Oklahoma Press, 2016.

Maclear, Kyo. Virginia Wolf. Illustrated by Isabelle Arsenault, Kids Can Press, 2012.

Marcus, Laura. 'Some Ancestral Dread': Woolf, Autobiography, and the Question of Shame." Virginia Woolf and Heritage: Selected Papers from the Twenty-sixth Annual International Conference on Virginia Woolf. Ed. Jane de Gay. Clemson University Press, 2017, pp. 264-79.

Okker, Patricia. "Native American Literatures and the Canon: The Case of ZitkalaŠa." American Realism and the Canon. Ed. Tom Quirk and Gary Scharnhorst. University of Delaware Press, 1994, pp. 87-101.

Spack, Ruth. "Re-visioning Sioux Women: Zitkala-Ša’s Revolutionary American Indian Stories." Legacy, vol. 14, no. 1, 1997, pp. 25-42.

Stanley, Sandra Kumamoto. "Claiming a Native American Identity: Zitkala-Sa and Autobiographical Strategies." Pacific Coast Philology, vo. 29, no. 1, 1994, pp. 64-69.

Woolf, Virginia. "The New Biography." Collected Essays Vol. IV. Harcourt, 1967, pp. 229-35.

A Room of One's Own. 1929. Annotated by Susan Gubar. Gen. Ed. Mark Hussey. Harcourt, 2005.

.A Sketch of the Past." Moments of Being. Ed. Jeanne Schulkind. Harcourt, 1985, pp. 64-137.

To the Lighthouse. Annotated by Mark Hussey. Ged. Ed. Mark Hussey. Harcourt, 2005.

Zitkala-Ša. American Indian Stories, Legends, and Other Writings. Ed. Cathy N. Davidson and Ada Norris. Penguin, 2003.

Recebido em: 21/11/2020

Aceito em: 02/02/2021 